Volume 2 Nomor 2, Juli-Desember 2018: hlm. 121-128.

Magister Ilmu Hukum, Fakultas Hukum, Universitas Lampung,

Bandar Lampung, Lampung, Indonesia.

E-ISSN: 2598-3105 P-ISSN: 2723-2581

http://jurnal.fh.unila.ac.id/index.php/cepalo
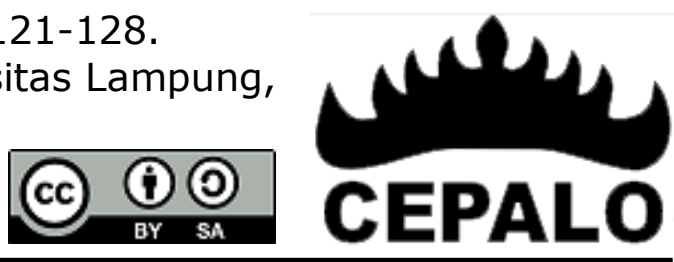

\title{
PENGEMBALIAN GANTI RUGI KEUANGAN NEGARA PADA PERKARA TINDAK PIDANA KORUPSI
}

\section{REPAYMENT OF COMPENSATION FOR STATE FINANCES IN CORRUPTION CASES}

\author{
Yayan Indriana \\ Pemerintah Daerah Provinsi Lampung \\ Yayanindriana10@gmail.com
}

\begin{abstract}
Abstrak
Problematika sistem penegakan hukum dan sanksi untuk tindak pidana korupsi tidaklah cukup hanya penjatuhan sanksi pidana penjara saja melainkan juga harus dilakukan upaya pengembalian kerugian negara yang ditimbulkan. Permasalahan dalam penelitian ini adalah bagaimanakah kajian hukum terhadap pengembalian ganti rugi keuangan negara pada perkara tindakan korupsi dan mengapa terdapat penyebab penghambat dalam pengembalian ganti rugi keuangan negara pada perkara tindak pidana korupsi. Penulisan ini bertujuan agar masyarakat mengetahui cara pengembalian ganti rugi yang disebabkan oleh pelaku korupsi, sehingga menjadi gambaran agar masyarakat lainnya tidak terjerumus dalam tindak pidana korupsi. Dalam penulusan ini, penulis menggunakan metode yuridis normatif di mana penelitian ini berfokus pada pengolahan data bersumber dari buku dan data-data yang didapatkan secara tidak langsung atau tanpa observasi Ke lapangan.
\end{abstract}

Kata Kunci: Pengembalian Ganti Rugi Keuangan Negara, Tindakan Pidana Korupsi.

\begin{abstract}
The problem of the system of law enforcement and sanctions for corruption is not enough just imprisonment but also efforts must be made to recover the losses caused by the state. The problem in this research is how is the legal study of returning state financial compensation in cases of corruption and why there are causes of obstacles in returning state financial compensation in cases of corruption. This writing aims to let the public know how to recover damages caused by corruptors, so that it becomes an illustration so that other communities do not fall into corruption. In this graduation, the author uses the normative juridical method in which this research focuses on processing data sourced from books and data obtained indirectly or without observation to the field.
\end{abstract}

Keywords: Repayment of State Financial Compensation, Corruption Crime.

Cara Mengutip (How to Cite): Yayan Indriana, "Pengembalian Ganti Rugi Keuangan Negara Pada Perkara Tindak Pidana Korupsi”, Jurnal Cepalo, 2 (2), (2018): 121-128.

DOI: https://doi.org/10.25041/cepalo.v2no2.1769

\section{A. Pendahuluan}

Salah satu tujuan diundangkannya Undang-Undang Nomor 31 Tahun 1999 tentang Pemberantasan Tindak Pidana Korupsi jo Undang-Undang Nomor 20 Tahun 2001 adalah untuk mengembalikan kerugian negara. Oleh karena itu, penegakan hukum pidananya lebih mengutamakan pengembalian ganti rugi keuangan negara dari para pelaku tindak pidana korupsi. ${ }^{1}$ Pengembalian ganti rugi keuangan negara yang ditimbulkan dari hasil korupsi yang merupakan sistem dari penegakan hukum yang mengharuskan memang adanya suatu proses penghapusan hak atas aset pelaku dari negara selaku korban dengan cara dilakukan

\footnotetext{
${ }^{1}$ Purwaning M.Yanuar, Pengembalian Aset Hasil Korupsi, Bandung: Alumni, (2007), hlm. 20.
} 
dengan penyitaan, pembekuan, perampasan baik dalam kompetensi lokal, regional maupun internasional sehingga kekayaan dapat dikembalikan kepada negara (korban) yang sah. ${ }^{2}$

Lahirnya Undang-Undang Nomor 16 Tahun 2004 tentang Kejaksaan Republik Indonesia telah menempatkan kejaksaan sebagai salah satu lembaga yang menyelenggarakan penegakan hokum. Hal ini secara jelas diatur dalam Pasal 2 ayat (1) Undang-Undang Nomor 16 Tahun 2004 tentang Kejaksaan Republik Indonesia yang menentukan bahwa "Kejaksaan Republik Indonesia yang selanjutnya dalam undang-undang ini disebut kejaksaan, adalah lembaga pemerintah yang melaksanakan kekuasaan negara di bidang penuntutan, serta kewenangan lain berdasarkan undang-undang". Adapun mengenai tugas dan Kewenangan kejaksaan dalam bidang pidana diatur dalam Pasal 30 ayat (1) Undang- Undang Nomor 16 Tahun 2004 tentang Kejaksaan Republik Indonesia meliputi:

a. Dapat melakukan penuntutan;

b. Melaksanakan ketetapan hakim dan keputusan pengadilan yang mempunyai kekuatan hukum tetap;

c. Melakukan pengawasan terhadap pelaksanaan putusan pidana bersyarat, putusan pidana pengawasan dan keputusan lepas bersyarat;

d. Melakukan penyidikan terhadap tindak pidana khusus berdasarkan undang- undang yang berlaku;

e. Melengkapi berkas perkara yang khusus dan untuk itu dapat melakukan pemeriksaan tambahan sebelum dilimpahkan ke pengadilan yang pelaksanaannya dikoordinasikan dengan penyidik.

Berdasarkan keputusan pengadilan yang telah memiliki kekuatan hukum tetap berupa perintah kepada terdakwa untuk membayar uang pengganti atas ganti rugi keuangan negara yang disebabkan oleh tindakan para orang yang tidak bertanggungjawab akan menjadi sia-sia apabila Jaksa sebagai eksekutor tidak menjalankan wewenangnya untuk melaksanakan upaya-upaya pengembalikan kerugian keuangan negara dengan mendasar pada putusan pengadilan. Berdasarkan latar belakang tersebut maka diperlukan adanya penelitian tentang "Pengembalian Ganti Rugi Keuangan Negara pada Perkara Tindak Pidana Korupsi". Permasalahan yang akan dibahas dalam penelitian ini adalah terkait bagaimana kajian hukum pengembalian ganti rugi keuangan negara pada perkara tindak pidana korupsi? Dan apa saja faktor penghambat dalam pengembalian kerugian keuangan negara pada perkara tindak pidana korupsi? Metode yang digunakan dalam penelitian ini adalah metode penelitian yuridis empiris dengan data primer hasil wawancara dan data sekunder dari buku serta literature.

\section{B. Pembahasan}

1. Kajian Hukum Pengembalian Ganti Rugi Keuangan Negara pada Perkara Tindak Pidana Korupsi Pengembalian kerugian negara merupakan suatu upaya yang memang harus dijalankan untuk memulihkan kembali perekonomian negara yang mengakibatkan tindak pidana korupsi, akan tetapi berada didalam lingkup Undang-Undang Pemberantasan Tindak Pidana Korupsi yang tidak langsung justru telah memberikan peluang bagi Terpidana untuk menentukan pilihan apakah akan membayar pidana pengganti atau memilih untuk menjalani pidana yang telah ditentukan dalam putusan Hakim. Hal tersebut dapat diketahui dalam rumusan Pasal 18 ayat (1) huruf b Undang-Undang Pemberantasan Tindak Pidana Korupsi yang menyebutkan "selain pidana tambahan sebagaimana dimaksud dalam Kitab Undang-Undang Hukum Pidana, sebagai pidana tambahan adalah $b$. pembayaran uang pengganti yang jumlahnya sebanyak harta benda yang diperoleh dari tindak pidana korupsi".

Selanjutnya dalam Pasal 18 ayat (2) Undang-Undang Pemberantasan Tindak Pidana Korupsi disebutkan "jika terpidana tidak membayar uang pengganti sebagaimana dimaksud dalam ayat (1) huruf b paling lama dalam waktu 1 (satu) bulan sesudah putusan pengadilan yang telah memperoleh kekuatan hukum tetap, maka harta bendanya dapat disita oleh jaksa dan dilelang untuk menutupi uang pengganti tersebut", adapun Pasal 18 ayat (3) Undang-Undang Pemberantasan Tindak Pidana Korupsi menyebutkan "dalam hal terpidana tidak mempunyai harta benda yang mencukupi untuk membayar uang pengganti sebagaimana dimaksud dalam ayat (1) huruf $b$, maka dipidana dengan pidana penjara yang lamanya tidak melebihi ancaman pidana maksimum dari pidana pokoknya sesuai dengan ketentuan dalam undang-undang ini dan karenanya pidana tersebut sudah ditentukan dalam putusan pengadilan".

Menurut Eddy Rifai, uang pengganti adalah salah satu hukuman pidana tambahan dalam perkara tindak pidana korupsi yang harus dibayar oleh Terpidana kepada negara yang jumlahnya sebanyak-banyaknya sama dengan harta benda yang diperoleh dari tindak pidana korupsi, apabila terdapat ketidakmampuan Terpidana

\footnotetext{
${ }^{2}$ Indriyanto Seno Adji, Korupsi dan Penegakan Hukum, Jakarta: Diadit Media, (2009), hlm 149.
} 
membayar uang pengganti tersebut, maka dapat diganti dengan pidana badan sebagai hukuman subsider. ${ }^{3}$ Selanjutnya menurut Novian Saputra, penjatuhan pidana pokok merupakan suatu keharusan yang dilakukan oleh Hakim dengan mendasar pada surat dakwaan Penuntut Umum serta segala sesuatu yang terbukti di persidangan, sedangkan penjatuhan pidana tambahan adalah bersifat pilihan dengan mendasar pada Pasal 18 Undang-Undang Pemberantasan Tindak Pidana Korupsi. Hakim menjatuhkan pidana tambahan berupa pembayaran uang pengganti, maka besarnya nilai yang harus dibayarkan sangat bergantung dari hasil audit kerugian keuangan negara disesuaikan dengan fakta persidangan mengenai besarnya uang yang diterima oleh Terdakwa, apakah hasil korupsi yang diperoleh terdakwa telah dikembalikan ke negara, serta apakah tindak pidana korupsi dilakukan secara bersama-sama sehingga pembayaran uang pengganti dapat dibebankan secara bersama-sama terhadap para Terdakwa. ${ }^{4}$

Menurut Eka Afta Rini, setelah adanya putusan pengadilan berkekuatan hukum tetap, upaya Jaksa dalam melakukan penagihan pembayaran uang pengganti terhadap Terpidana meliputi langkah-langkah administrasi sebagai berikut:

a. Membuat surat tagihan dengan perihal penagihan uang ganti rugi kepada Terpidana untuk menghadap Jaksa eksekutor di kantor Kejaksaan setempat;

b. Terpidana dipanggil dan harus menghadap Jaksa guna menjelaskan mengenai kesanggupan untuk membayar ganti rugi uang negara yang telah ditetapkan oleh pengadilan yang mempunyai kekuatan hukum tetap. Pada tahap ini dibuatkan surat pernyataan yang berisi sanggup atau tidaknya membayar uang ganti rugi uang negara. Tetapi jika Terpidana tidak bisa membayar maka harus dibuktikan dengan keterangan pejabat yang berwenang;

c. Pada saat pembayaran uang ganti rugi, harus diberikan tanda terima pembayaran uang yang telah diterima dari Terpidana dan ditanda tanggani oleh Kepala Kejaksaan Negeri setempat;

d. Pada saat penerimaan uang ganti rugi dari Terpidana maka Kepala Kejaksaan setempat memerintahkan Jaksa eksekutor untuk menyetorkan uang pengganti Terpidana dengan bukti formulir Surat Setoran Penerima Negara Bukan Pajak melalui bank. ${ }^{5}$

Menurut analisa penulis, upaya pengembalian kerugian keuangan negara atas terjadinya tindak pidana korupsi secara yuridis dapat dimulai dari tahap penyidikan, tahap penuntutan dan tahap eksekusi atau pelaksanaan putusan pengadilan.

\section{a. Tahap Penyidikan}

Bekaitan dengan proses penyidikan, apabila Tersangka dikenakan Pasal 2 dan Pasal 3 Undang-Undang Pemberantasan Tindak Pidana Korupsi maka Penyidik dapat meminta bantuan dan atau melibatkan Badan Pemeriksa Keuangan (BPK) atau Badan Pengawas Keuangan dan Pembangunan (BPKP) sebagai instansi yang memiliki kompetensi untuk menghitung jumlah kerugian negara yang ditimbulkan akibat dari perbuatan Tersangka. Selain melakukan pemanggilan dan pemeriksaan terhadap saksi-saksi serta melakukan penangkapan dan penahanan terhadap Tersangka, Penyidik juga dapat melakukan penyitaan terhadap bendabenda milik Tersangka yang terdapat hubungannya dengan tindak pidana korupsi, termasuk harta yang dimiliki Tersangka yang memang diduga dipergunakan atau diperoleh dari pendapatan tindak pidana korupsi. Penyitaan tersebut bertujuan agar Tersangka tidak menjual atau mengalihkan kepemilikannya kepada orang lain, disamping itu dengan dilakukannya penyitaan dapat memudahkan Jaksa ekskutor untuk melakukan lelang guna mengembalikan kerugian keuangan negara apabila dalam proses persidangan Tersangka dinyatakan terbukti melakukan tindak pidana korupsi.

\section{b. Tahap Penuntutan.}

Optimalisasi kewenangan Penuntut Umum dalam peradilan dapat diaplikasikan dengan cara meminta Hakim melalui surat tuntutan pidana agar menjatuhkan pidana tambahan berupa menghukum Terdakwa untuk mengembalikan ganti rugi uang negara atas tindak pidana korupsi yang dilakukannya dengan mendasar pada ketentuan Pasal 18 ayat (1) huruf b Undang-Undang Pemberantasan Tindak Pidana Korupsi. Disamping itu, Penuntut Umum juga dapat meminta kepada Hakim untuk menetapkan agar barang yang telah dilakukan penyitaan pada saat proses penyidikan dirampas agar dapat dilakukan lelang guna menutupi

\footnotetext{
${ }^{3}$ Wawancara dengan Eddy Rifai selaku Dosen Fakultas Hukum Universitas Lampung, pada tanggal 13 Juli 2018, pukul 14.30 WIB.

${ }^{4}$ Wawancara dengan Novian Saputra selaku Hakim pada Pengadilan Negeri Tanjung Karang, tanggal 12 Juli 2018, pukul 15.30 WIB.

${ }^{5}$ Wawancara Eka Afta Rini selaku Jaksa pada Kejaksaan Negeri Bandar Lampung, tanggal 13 Juli 2018, pukul 09.00 WIB.
} 
kerugian negara yang ditimbulkan. Atas terbuktinya kerugian keuangan negara dengan jumlah yang dituntut oleh Penuntut Umum dijadikan sebagai dasar untuk menghukum Terdakwa agar membayar uang pengganti sebesar nilai kerugian negara yang ditimbulkan.

c. Tahap eksekusi atau pelaksanaan putusan pengadilan

Pasal 270 KUHAP menentukan bahwa pelaksanaan keputusan pengadilan yang telah mendapatkan kekuatan hukum tetap itu dilaksanakan oleh Jaksa. Eksekusi putusan pengadilan hanya dapat dilakukan berdasarkan substansi yang termuat dalam amar putusan, berkaitan dengan pengembalian kerugian keuangan negara melalui hukuman pembayaran ganti rugi uang negara jika Terpidana tidak dapat mengembalikan, maka Jaksa dapat melakukan penyitaan dan lelang atas harta benda yang telah ditetapkan dalam amar putusan, proses penyitaan tersebut tidak lagi memerlukan izin atau penetapan pengadilan sebab telah menjadi satu kesatuan dengan putusan pokok perkara. Akan tetapi apabila aset yang disita dan dilelang tidak mencukupi untuk membayar pengembalian dana ganti rugi Terpidana harus menjalani hukuman pidana yang lamanya telah ditentukan dalam putusan, selain itu diluar konteks putusan pengadilan Jaksa Pengacara Negara juga dapat melakukan gugatan perdata melalui pengadilan sebagai upaya untuk mengembalikan kerugian keuangan negara.

Setelah mencermati substansi yang termuat dalam Pasal 18 ayat (2) Undang- Undang Pemberantasan Tindak Pidana Korupsi diketahui bahwa terdapat kalimat "harta bendanya dapat disita dan dilelang", menurut penulis harta benda yang dimaksud dalam pasal tersebut adalah aset yang milik Terdakwa yang memang bukan merupakan pendapatan dari tindakan pidana korupsi atau bukan merupakan aset yang digunakan untuk melaksanakan tindak pidana korupsi, sebab apabila berdasarkan persidangan terbukti bahwa harta benda yang dirampas adalah merupakan harta benda hasil tindak pidana korupsi maka berlaku ketentuan Pasal 18 ayat (1) huruf a Undang-Undang Pemberantasan Tindak Pidana Korupsi sehingga Jaksa tidak perlu melakukan penyitaan dan lelang dengan mendasar pada Pasal 18 ayat (2) Undang-Undang Pemberantasan Tindak Pidana Korupsi. Selanjutnya berdasarkan Pasal 18 ayat (3) Undang-Undang Pemberantasan Tindak Pidana Korupsi ditentukan "dalam hal terpidana tidak mempunyai harta benda yang mencukupi untuk membayar uang pengganti sebagaimana dimaksud dalam ayat (1) huruf b, maka dipidana dengan pidana penjara yang lamanya tidak melebihi ancaman maksimum dari pidana pokoknya sesuai dengan ketentuan dalam undang-undang ini dan lamanya pidana tersebut sudah ditentukan dalam putusan pengadilan". Menurut penulis, ketentuan pasal tersebut dinilai sebagai pidana subsider bagi Terpidana yang baru dapat berlaku apabila:

a Terpidana tidak memiliki aset yang memenuhi untuk membayar uang ganti rugi, disamping itu dalam tahap waktu 1 bulan setelah keputusan pengadilan mendapatkan kekuatan hukum tetap ternyata tidak dapat memberikan uang ganti rugi dan pendapatan lelang dari harta benda tidak memenuhi untuk memberikan uang ganti rugi;

b. Proses yang lama dalam pemidanaan kurungan pengganti tidak melebihi ancaman kurungan maksimal dari pasal yang telah ditetapkan;

c. Lamanya pidana kurungan pengganti telah ditentukan dalam putusan pengadilan, penentuan lamanya pidana penjara dimaksudkan sebagai upaya untuk mengakomodir apabila uang ganti rugi tidak dapat dibayarkan keseluruhan atau sebagian oleh Terpidana.

Selain menggunakan instrumen hukum pidana, Undang-Undang Pemberantasan Tindak Pidana Korupsi memang mengatur mengenai tindakan pengembalian kerugian negara dengan menggunakan intrumen hukum perdata melalui pengajuan gugatan yang dapat dilakukan oleh dilaksanakan oleh Jaksa sebagai Penegak hukum Negara atau lembaga yang dirugikan atas terjadinya kerugian keuangan negara terhadap pelaku atau ahli warisnya dengan mendasar pada ketentuan sebagai berikut:

a. Pasal 32 Undang-Undang Pemberantasan Tindak Pidana Korupsi yang menentukan bahwa:

1) Dalam hal penyidik menemukan dan berpendapat bahwa satu atau lebih unsur tindak pidana korupsi tidak terdapat cukup bukti, sedangkan secara nyata telah ada kerugian keuangan negara, maka penyidik segera menyerahkan berkas perkara hasil penyidikan tersebut kepada Jaksa Pengacara Negara untuk dilakukan gugatan perdata atau diserahkan kepada instansi yang dirugikan untuk mengajukan gugatan.

2) Putusan bebas dalam perkara tindak pidana korupsi tidak menghapuskan hak untuk menuntut kerugian terhadap keuangan negara.

b. Pasal 33 Undang-Undang Pemberantasan Tindak Pidana Korupsi yang menentukan bahwa, dalam hal tersangka meninggal dunia pada saat dilakukan penyidikan, sedangkan secara nyata telah ada kerugian 
keuangan negara, maka penyidik segera menyerahkan berkas perkara hasil penyidikan tersebut kepada Jaksa Pengacara Negara atau diserahkan kepada instansi yang dirugikan untuk dilakukan gugatan perdata terhadap ahli warisnya.

c. Pasal 34 Undang-Undang Pemberantasan Tindak Pidana Korupsi yang menentukan bahwa, dalam hal terdakwa meninggal dunia pada saat dilakukan pemeriksaan di sidang pengadilan, sedangkan secara nyata telah ada kerugian keuangan negara, maka penuntut umum segera menyerahkan salinan berkas berita acara sidang tersebut kepada Jaksa Pengacara Negara atau diserahkan kepada instansi yang dirugikan untuk dilakukan gugatan perdata terhadap ahli warisnya.

d. Pasal 38C Undang-Undang Pemberantasan Tindak Pidana Korupsi yang menentukan bahwa, apabila setelah putusan pengadilan telah memperoleh kekuatan hukum tetap, diketahui masih terdapat harta benda milik terpidana yang diduga atau patut diduga juga berasal dari tindak pidana korupsi yang belum dikenakan perampasan untuk negara sebagaimana dimaksud dalam Pasal 38 B ayat (2), maka negara dapat melakukan gugatan perdata terhadap terpidana dan atau ahli warisnya.

Adapun hal-hal yang harus dibuktikan oleh Jaksa Penegak Hukum Negara maupun lembaga yang dirugikan dalam hal kedudukannya sebagai penuntut antara lain meliputi:

a. Adanya kerugian keuanan negara secara nyata;

b. Kerugian keuangan negara yang ditimbulkan merupakan resiko atau bersangkutan dengan perbuatan Tersangka, Terdakwa atau Terpidana;

c. Adanya aset milik Tersangka, Terdakwa atau Terpidana yang dapat digunakan untuk pengembalian ganti rugi keuangan negara.

\section{Faktor Penghambat dalam Pengembalian Kerugian Keuangan Negara pada Perkara Tindak Pidana Korupsi}

Penegakan hukum mempunyai peranan yang besar dalam penyelenggaraan kehidupan bangsa dan negara untuk menjamin kepentingan mayoritas masyarakat atau warga negara, dapat menjamin kepastian hukum, keadilan, dan kebenaran serta mengahargai hak asasi manusia, sehingga berbagai tindakan kriminal dan tindakan semena-mena yang dilakukan anggota masyarakat atas anggota masyarakat lainnya akan dapat dihindarkan. Penegakan hukum yang konsisten dapat mewujudkan harapan masyarakat dengan kepastian dan ketetapan hukum yang berlandaskan keadilan dan kebenaran. ${ }^{6}$

Upaya pengembalian ganti rugi keuangan negara sebagai resiko dari tindakan pidana korupsi tidak dapat dilepaskan dari adanya faktor-faktor yang mempengaruhinya, sebagaimana dikemukakan oleh Soerjono Soekanto, penegakan hukum pada dasarnya bukan semata-mata menerapkan ketentuan peratuan perundangundangan saja, namun terdapat juga faktor-faktor yang mempengaruhinya, yaitu sebagai berikut: ${ }^{7}$

a. Faktor Perundang-undangan (Substansi hukum)

b. Faktor penegakan hokum

c. Faktor sarana dan fasilitas

d. Faktor masyarakat

e. Faktor Kebudayaan.

Menurut Eddy Rifai, proses penyelidikan dan penyidikan yang tidak maksimal memberikan sumbangsih yang paling besar apabila pelaksanaan pengembalian kerugian keuangan negara menemui hambatan, sebab salah satu kewenangan yang dimiliki oleh Penyelidik sebagaimana diatur dalam Pasal 5 ayat (1) KUHAP adalah mencari keterangan dan barang bukti, pada tahap ini Penyelidik harus semaksimal mungkin mampu mencari dan menemukan aset-aset milik pelaku tindak pidana korupsi, sehingga pada saat perkara tersebut ditingkatkan ketahap penyidikan maka Penyidik dapat langsung melakukan penyitaan terhadap aset- aset yang ada untuk mengindari terjadinya pengalihan aset oleh Tersangka kepada orang lain.

Penyitaan terhadap aset milik Tersangka berhubungan dengan pidana tambahan berupa perampasan yang dapat ditetapkan bersamaan dengan penjatuhan pidana pokok oleh Hakim sehingga hal tersebut dapat mempermudah Jaksa eksekutor untuk mengembalikan kerugian negara. Akan tetapi yang seringkali terjadi Penyidik justru lebih mengedepankan perhitungan kerugian negara dan pemenuhan unsur pidana dengan tujuan bahwa terhadap hasil dari perhitungan kerugian keuangan negara tersebut dapat dimintakan pengembalian melalui pembayaran uang pengganti kepada negara. ${ }^{8}$

\footnotetext{
${ }^{6}$ Sunarto, Keterpaduan dalam Penanggulangan Kejahtatan, Bandar Lampung: Anugrah Utama Raharja, (2016), hlm 47-48.

${ }^{7}$ Soerjono Soekanto, Faktor-Faktor yang Mempengaruhi Penegakan Hukum, Bandung: Rineka Cipta, (1986), hlm 8-11.

${ }^{8}$ Wawancara dengan Eddy Rifai selaku Dosen Fakultas Hukum Universitas Lampung, pada tanggal 13 Juli 2018, pukul 14.30 WIB.
} 
Unsur yang mengakibatkan kerugian keuangan negara dalam Undang-Undang Tindak Pidana Korupsi merupakan hal yang harus terpenuhi dalam upaya pengembalian ganti rugi keuangan negara. Mengingat perbuatan korupsi seringkali dilakukan oleh orang yang mempunyai jabatan serta berpendidikan tinggi, tentunya setiap pelaku korupsi akan tindakan-tindakan yang sistematis dan terstrukrur untuk menyembunyikan hasil yang diperoleh dari perbuatan korupsi sehingga dapat menyulitkan Penyidik dalam melakukan penyitaan terhadap aset yang diperoleh dari perbuatan korupsi tersebut. Tidak dapat dipungkiri bahwa kesulitan melakukan penyitaan harta benda yang dialami oleh Penyidik seringkali berdampak pada tindakan Penyidik yang terfokus pada penyitaan surat-surat atau dokumen-dokumen tertulis yang dipergunakan untuk mengetahui jumlah kerugian keuangan negara yang ditimbulkan, hal tersebut tentunya hanya dapat dipergunakan untuk membuktikan kesalahan pelaku yang bertujuan untuk menjatuhkan pidana penjara, sedangkan untuk pelaksanaan perampasan, lelang, maupun pembayaran uang pengganti sebagai pidana tambahan menjadi terhambat.

Kesulitan Penyidik melakukan penyitaan juga didasarkan pada adanya batasan mengenai benda sebagaimana diatur dalam Pasal 39 ayat (1) KUHAP yang menentukan bahwa, yang dapat dikenakan penyitaan adalah:

a. Harta benda atau tagihan Tersangka atau Terdakwa yang seluruh atau sebagian diduga didapatkan dari tindak pidana atau sebagai hasil dari tindak pidana;

b. Benda yang telah dipergunakan secara langsung untuk melakukan tindak pidana atau untuk mempersiapkannya;

c. Benda yang dipergunakan untuk menghalang-halangi penyidikan tindak pidana;

d. Benda yang khusus dibuat atau diperuntukkan melakukan tindak pidana;

e. Benda lain yang mempunyai hubungan langsung dengan tindak pidana yang dilakukan.

Menurut Novian Saputra, terikat dengan penjatuhan pidana berupa pembayaran uang ganti rugi yang dapat dijadikan sebagai dasar untuk mengembalikan kerugian keuangan negara pada dasarnya terdapat beberapa kendala sehingga putusan tersebut terkesan menjadi sia-sia, antara lain: ${ }^{9}$

a. Adanya rentang waktu yang cukup lama antara terjadinya perbuatan korupsi dengan proses persidangan menimbulkan kesulitan untuk menelusuri uang atau hasil tindak pidana korupsi.

b. Uang atau pendapatan tindakan pidana korupsi telah habis atau telah dilakukan dalam bentuk lain yang sulit dijangkau oleh hukum.

c. Ketidakmampuan Terpidana untuk membayar uang pengganti.

Menurut Eka Afta Rini, tidak terlaksananya penyitaan dan lelang terhadap harta benda milik Terpidana disebabkan oleh faktor kesulitan Jaksa dalam menemukan harta benda milik Terpidana, meskipun demikian Jaksa selaku pelaksana putusan pengadilan dapat melakukan eksekusi pidana penjara sebagai pengganti atas tidak dibayarkannya uang pengganti oleh Terpidana. ${ }^{10}$ Pasal 32, Pasal 33, Pasal 34, dan Pasal 38C UndangUndang Pemberantasan Tindak Pidana Korupsi juga memberikan dasar hukum bagi Jaksa Penegak Hukum Negara maupun lembaga yang dirugikan untuk melakukan upaya pengembalian kerugaian negara dengan menggunakan perintah gugatan perdata.

Menurut Eka Afta Rini, sama halnya dengan upaya pengembalian kerugian negara melalui instrumen pidana terkait dengan pengajuan gugatan perdata hambatan yang dialami oleh Jaksa Penegak Hukum Negara maupun lembaga yang dirugikan mendasar pada kesulitan untuk menemukan harta benda milik Terpidana. Disamping itu selain proses pemeriksaan persidangan yang membutuhkan waktu lama, hambatan lain terkait pengajuan gugatan perdata adalah keterbatasan anggaran yang disediakan untuk menjukan gugatan perdata untuk membayar biaya-biaya yang terdiri dari:
a. Pendaftaran kuasa;
b. Pendaftaran gugatan;
c. Pemanggilan saksi;
d. Sita jaminan;
e. Sita eksekusi;
f. Eksekusi lelang;
g. Pemeriksaan setempat.

\footnotetext{
${ }^{9}$ Wawancara dengan Novian Saputra selaku Hakim pada Pengadilan Negeri Tanjung Karang, tanggal 12 Juli 2018, pukul 15.30 WIB.

${ }^{10}$ Wawancara Eka Afta Rini selaku Jaksa pada Kejaksaan Negeri Bandar Lampung, tanggal 13 Juli 2018, pukul 09.00 WIB.
} 
Menurut penulis, faktor penghambat dalam upaya pengembalian ganti rugi uang negara akibat tindak pidana korupsi dapat diuraikan sebagai berikut:

a. Faktor peraturan perundang-undangan.

Secara yuridis, diaturnya ketentuan Pasal 17, Pasal 18, Pasal 32, Pasal 33, Pasal 34, dan Pasal 38C Undang-Undang Pemberantasan Tindak Pidana Korupsi tidak memberikan celah bagi setiap pelaku tindak pidana korupsi dapat lepas dari pertanggungjawaban pidana maupun menghindari upaya penyitaan, perampasan, lelang, serta pembayaran uang pengganti.

Berkaitan dengan penyitaan, KUHAP sebagai induk dari pelaksanaan hukum acara pidana telah memberikan batasan bahwa harta yang dapat disita hanyalah benda-benda yang merupakan hasil tindakan pidana korupsi maupun benda- benda yang digunakan pada saat dilakukannya tindak pidana korupsi maupun benda-benda yang ada pada pihak ketiga tetapi harus mempunyai hubungan atau keterkaitan dengan tindakan pidana korupsi. Mengingat tindakan pidana korupsi termasuk dalam kejahatan luar biasa dengan pelaku yang memiliki latar belakang pendidikan tinggi, maka dengan tunduknya penanganan perkara tindak pidana korupsi terhadap KUHAP dapat memberikan peluang bagi setiap pelaku untuk melakukan upaya-upaya yang berpotensi membuat Penyidik tidak dapat melakukan penyitaan terhadap harta benda milik pelaku. Sebagaimana diketahui bahwa terlaksananya penyitaan terhadap harta benda milik pelaku akan menentukan keberhasilan upaya perampasan, lelang, serta pembayaran uang ganti sebagai pengembalian ganti rugi keuangan negara.

b. Faktor penegak hukum.

Rendahnya keberhasilan Penyidik dalam melakukan penyitaan terhadap harta benda milik pelaku tindak pidana korupsi tidak dapat dipisahkan dari adanya sudut pandang bahwa pengembalian kerugian negara merupakan pidana subsider, sedangkan yang menjadi pidana primernya adalah penjatuhan pidana penjara. Meskipun Undang-Undang Pemberantasan Tindakan Pidana Korupsi memberikan opsi terkait penindakan perkara korupsi yang terdiri dari penjatuhan pidana dan pengembalian kerugian negara melalui pidana tambahan serta gugatan perdata, akan tetapi mengingat dampak yang ditimbulkan akibat tindak pidana korupsi memberikan pengaruh terhadap keuangan negara, maka sudah sepatutnya apabila aparat penegak hukum lebih mengedepankan upaya pengembalian kerugian negara dibandikan dengan penjatuhan pidana penjara.

c. Faktor sarana dan prasarana

Berkaitan dengan pengembalian kerugian negara melalui mekanisme pengajuan gugatan perdata diketahui adanya hambatan berupa tidak tersedianya anggaran yang memadai guna membayar biaya-biaya yang dari pendaftaran kuasa, pendaftaran gugatan, pemanggilan saksi, sita jaminan, sita eksekusi, eksekusi lelang, dan pemeriksaan setempat.

d. Faktor masyarakat.

Masalah yang sering timbul dalam masyarakat yang dapat mempengaruhi pengembalian ganti rugi keuangan negara akibat tindakan pidana korupsi adalah: Rendahnya kesadaran masyarakat untuk melaporkan kepada aparat penegak hukum apabila mengetahui terjadinya tindak pidana korupsi; Daya dukung yang rendah bagi masyarakat yang menjadi saksi dalam proses persidangan didasarkan pada rasa khawatir dan takut apabila keterangan yang diberikan di persidangan akan berdampak pada kepentingan pribadi masyarakat, sebab hampir sebagaian besar pelaku tindak pidana korupsi adalah orang yang mempunyai kedudukan, jabatan, serta berpengetahuan tinggi.

e. Faktor kebudayaan.

Faktor kebudayaan memiliki korelasi dengan faktor aparat penegak hukum, mendasar pada contoh putusan yang dipergunakan dalam penelitian ini diketahui bahwa Jaksa eksekutor belum dapat melakukan upaya pengembalian kerugian negara dengan mendasar pada putusan Hakim tersebut, terjadinya penundaan dan penanganan yang berlarut-larut dikhawatirkan dapat menjadi sebuah kebiasaan dikalangan Jaksa eksekutor sehingga dapat menghambat proses pengembalian ganti rugi keuangan negara akibat tindakan pidana korupsi.

\section{Penutup}

Berdasarkan hasil pembahasan maka dapat disimpulkan bahwa pengembalian ganti rugi keuangan negara akibat tindakan pidana korupsi dapat dilaksanakan melalui 2 (dua) mekanisme, yaitu:

1. Mekanisme hukum pidana dengan mendasar pada ketentuan Pasal 18 Undang-Undang Pemberantasan Tindak Pidana Korupsi.

2. Mekanisme hukum perdata melaui pengajuan gugatan dengan mendasar pada Pasal 32, Pasal 33, Pasal 34 
dan Pasal 38C Undang-Undang Pemberantasan Tindak Pidana Korupsi.

Faktor penghambat upaya pengembalian ganti rugi keuangan negara akibat tindakan pidana korupsi disebabkan oleh tidak dilakukannya penyitaan terhadap harta benda milik Terpidana, hal tersebut terjadi karena pada saat berlangsungnya proses penyelidikan maupun penyidikan tidak berhasil menemukan harta benda milik Terpidana atas upaya penelusuran maupun pelacakan yang dilakukan oleh Penyidik sehingga upaya penyitaan maupun perampasan untuk melakukan lelang guna membayar uang pengganti tidak dapat dilaksanakan.

Dengan demikian maka tidak ada pilihan lain selain menerapkan pidana subsider berupa pidana penjara terhadap Terpidana yang telah ditentukan dalam putusan pengadilan sebagai pengganti atas kewajiban pengembalian kerugian keuangan negara. Pengembalian kerugian negara melalui upaya gugatan perdata juga terhambat oleh faktor tidak ditemukannya harta benda milik Terpidana sehingga tidak dapat dimohonkan sita jaminan kepada pengadilan, disamping itu tidak tersedianya anggaran yang memadai guna melakukan gugatan perdata juga menjadi hambatan bagi Jaksa Pengacara Negara maupun instansi yang dirugikan.

Berkaitan dengan melakukan penegakan hukum mengusulkan kepada aparat penegak hukum yang memiliki kewenangan dalam melakukan pemeriksaan perkara tindak pidana korupsi untuk dapat semaksimal mungkin malakukan upaya penelusuran dan pelacakan guna menemukan aset atau harta benda milik Tersangka guna menunjang keberhasilan pengembalian kerugian keuangan negara.

Berkaitan dengan adanya faktor penghambar, disarankan agar setiap lembaga apparat hukum yang berwenang melakukan tindakan perkara tindakan pidana korupsi agar dapat lebih melakukan pembenahan strukturan guna mencapai keberhasilan pengembalian kerugian keuangan negara.

\section{DAFTAR PUSTAKA}

\section{A. Buku}

M.Yanuar, Purwaning. (2007). Pengembalian Aset Hasil Korupsi. Bandung: Alumni.

Seno Adji, Indriyanto. (2009). Korupsi dan Penegakan Hukum. Jakarta: Diadit Media.

Soekanto, Soerjono. (1986). Faktor-Faktor yang Mempengaruhi Penegakan Hukum. Bandung: Rineka Cipta.

Sunarto. (2016). Keterpaduan dalam Penanggulangan Kejahtatan. Bandar Lampung: Anugrah Utama Raharja.

\section{B. Peraturan Perundang-Undangan}

Undang-Undang Nomor 31 Tahun 1999 tentang Pemberantasan Tindak Pidana Korupsi yang telah diubah dan ditambah dengan Undang-Undang Nomor 20 Tahun 2001 tentang Perubahan atas Undang-Undang Nomor 31 Tahun 1999 tentang Pemberantasan Tindak Pidana Korupsi.

Undang-Undang Nomor 8 Tahun 1981 Tentang Kitab Undang-Undang Hukum Acara Pidana.

Undang-Undang Nomor 16 Tahun 2004 tentang Kejaksaan Republik Indonesia. 